\title{
Detection and Quantification of Preservatives in Green Cosmetics
}

\author{
Evren Alğın Yapar*, Nilay Civil, Ebru Üncüoğlu
}

Republic of Turkey Ministry of Health, Turkish Medicines And Medical Devices Agency, Vice Presidency of Economic Assessments and Laboratory Services, Department of Analysis and Control Laboratories, 06100 Sihhiye, Ankara, Turkey, Email: evrenalgin@yahoo.com, nilay.civil@titck.gov.tr, ebru.uncuoglu@titck.gov.tr

*Correspondence: evrenalgin@yahoo.com (Evren Alğın Yapar)

Received: 04 December 2018; Accepted: 26 December 2018; Published: 31 December 2018

\begin{abstract}
Preservatives are used in cosmetic formulations to provide protection against microbial growth to ensure the safety and the quality during their shelf life. Benzyl alcohol, sodium benzoate and sorbic acid are the preservatives that can be used in green cosmetic formulations. According to the cosmetic legislation usage of above indicated preservatives are restricted and thus determination and quantification of them from the cosmetic products have become important. In this study analytical methods are given to enable the determination of benzyl alcohol, sodium benzoate and sorbic acid. The methods are based on extracting the preservative agents from four different pharmaceutical form (solution, emulsion, gel and cream) of the various cosmetic matrices and later on detection in the scope of the basic chromatographic data and test parameters by High Performance Liquid Chromatography (HPLC) system with UV Detector.
\end{abstract}

Keywords: Cosmetic, Green, Organic, Preservative, HPLC-UV

\section{Introduction}

Preservatives are used in cosmetic formulations to provide protection against microbial growth for the safety of the product and to ensure microbiological quality during their shelf life. Personal care cosmetic products are often produced in solution, emulsion, gel and cream forms. In case of design and development of green cosmetic formulations, preservative decision and quantification become important. In this context benzyl alcohol, sodium benzoate and sorbic acid are some of the preservatives that can be used limitedly according to the legislation in green cosmetic formulations. Benzyl alcohol is an aromatic alcohol often used as fragrance component, solvent, preservative and viscosity reducing in cosmetics. ${ }^{1}$ Benzyl alcohol is also presented in green cosmetics as identical to nature. According to cosmetic legislation benzyl alcohol used as a preservative in maximum use of $1 \%$ concentration, use as fragrance $0.001 \%$ in cosmetics and personal care products. It is a component that should be listed on the label when used in concentrations higher than $0.001 \%$ in products and $0.01 \%$ in the rinse off products. ${ }^{2-4}$ Scientific articles include different methods such as High Perfomance Liquid Chromatography (HPLC), Gas Chromatography (GC) and Electrophoretic methods reporting the availibility of detection and determination of benzyl alcohol..$^{5-7}$ Benzoic acid is an aromatic acid that is used as $\mathrm{pH}$ regulator and preservative in various cosmetic products and also in green cosmetics as identical to nature. Benzoic acid is usually being used as sodium salt in the form of sodium benzoate 
due to being slightly soluble in water. Benzoic acid is found in the natural structure of many plants. It may be used in combination with other preservative agents. ${ }^{1,8}$ Benzoic acid, its salts and ethyl ester are also included in preservatives which may contain organic cosmetic products. ${ }^{9}$ The use of benzoic acid is restricted in cosmetic legislation. According to the cosmetic legislation rinse off products other than oral care products $2.5 \%$ (acid), oral care products $1.7 \%$ (acid), $0.5 \%$ (acid) in the product is allowed to be used in leave on products. ${ }^{10-11}$ Due to the widespread use of benzoic acid and its salts in cosmetic products quantification of benzoic acid is important. There are some studies that indicate the use of HPLC method for the detection and quantification of benzoic acid. ${ }^{12-13}$ Sorbic acid is another preservative commonly used in green cosmetics that is used as naturally identical or can be obtained directly from plants. Sorbic acid and its salts are among the limited-use preservatives, which can be used in cosmetic products, including organic cosmetics. Sorbic acid is usually used in the form of potassium salt, potassium sorbate. According to cosmetic legislation the use of sorbic acid in cosmetic products at $0.6 \%$ without any warning. ${ }^{9-11}$ Detection and quantification of sorbic acid have been studied with many studies by chromatographic methods such as HPLC and electrochemical methods such as polarography. ${ }^{14-16}$

The methods for above mentioned preservatives are also available for some other preservatives. The method used for benzyl alcohol also is available to determine methylisothiazolinone (MI), chloromethylisothiazolinone (CMI), potassium sorbate (PS), sodium benzoate (SB) and methyl paraben, the method used for sorbic acid allows determination of 4-hydroxybenzoic acid, salicylic acid and parabens as well as sorbic acid.6,7,17 Benzoic acid method is based on the calculation of benzoic acid via sodium benzoate.

Detection and quantification of limited ingredients are critical for development of cosmetic formulations and quality control of final cosmetic products. In this study, methods are given for the detection and quantification of the benzyl alcohol, the sodium benzoate and the sorbic acid that are widely used in cosmetics and allowed to use for green cosmetics. These methods are based on extracting preservative agents from the sample matrices and later on detection in the scope of the basic chromatographic data and test parameters in an HPLC system with UV Detector. ${ }^{17-18}$

\section{Material and Methods}

\subsection{Materials}

All standards; benzyl alcohol, sodium benzoate and sorbic acid were purchased from Sigma (St. Louis, MO, USA). Solvents used for preparation of mobile phases and eluents; acetonitrile, methanol and water used as HPLC grade. $0.1 \%$ formic acid was prepared by the appropriate dilution of the $99 \%$ formic acid with water. Potassium dihydrogen orthophosphate, ortho phosphoric acid, sulphuric acid concentrated, acetic acid glacial sodium acetate trihydrate and triethyl amine used as analytical reagent.

\subsection{Method}

All preservative agents were extracted with the help of the appropriate eluent for the method from the various cosmetic matrices (solution, gel, emulsion and cream forms) and these extracts were analysed by reverse phase HPLC (UV/DAD detector) according to retention times. Experiments were performed in an HPLC system (Agilent 
1260 Infinity II, Agilent Technologies, Germany) consisting a quaternary pump, an autosampler, a vacuum degasser, and a column compartment, coupled to a diode array detector. Bandelin Sonorex RK 100h (35 kHz, 80 W) ultrasonic bath (Bandelin Electronic Co., Germany) was used for sonication.

\section{Chromatographic conditions for benzyl alcohol}

Chromatography was performed under gradient conditions at a flow-rate of 1.0 $\mathrm{ml} / \mathrm{min}$. The mobile phase consisted of a mixture of buffer and acetonitrile with gradient program. Buffer solution was prepared as $0.1 \%$ formic acid in water. The detection was made at $257 \mathrm{~nm}$ and chromatographic separation was carried out on Supelcosil LC-ABZ $250 \mathrm{~mm} \times 4.6 \mathrm{~mm}, 5 \mathrm{~mm}$ (Supelco, Bellefonte, PA, USA) or equivalent column with $20 \mu \mathrm{l}$ injection. Column temperature was set on $20-22^{\circ} \mathrm{C}$.

The gradient elution details were as follows:

Table1. Gradient Programme

\begin{tabular}{ccc}
\hline Time (min) & Acetonitrile (A\%) & $\mathbf{0 , 1}$ Formic Acid (B\%) \\
\hline 0 & 15 & 85 \\
5 & 15 & 85 \\
7 & 25 & 75 \\
17 & 25 & 75 \\
19 & 15 & 85 \\
22 & 15 & 85 \\
\hline
\end{tabular}

\section{Chromatographic conditions for sodium benzoate}

Chromatography was performed under isocratic conditions at a flow-rate of 1.0 $\mathrm{ml} / \mathrm{min}$. The mobile phase consisted of a mixture of buffer and methanol $(60: 40, \mathrm{v} / \mathrm{v})$. Buffer solution was prepared by solving $6.8 \mathrm{~g}$ potassium dihydrogen ortho phosphate in $1000 \mathrm{ml}$ water, adding $1 \mathrm{ml}$ of triethyl amine and adjusting the pH to $5.5( \pm 0.1)$ with ortho phosphoric acid. The detection was made at $254 \mathrm{~nm}$ and chromatographic separation was carried out on RP $18250 \mathrm{~mm}$ x $4.0 \mathrm{~mm}, 10 \mathrm{~mm}$ column with $20 \mu \mathrm{l}$ injection.

\section{Chromatographic conditions for sorbic acid}

Chromatography was performed under gradient conditions at a flow-rate of 1.0 $\mathrm{ml} / \mathrm{min}$. The mobile phase consisted of a mixture of buffer and acetonitrile. Buffer solution was prepared by solving $6.35 \mathrm{~g}$ sodium acetate and $20 \mathrm{ml}$ acetic acid in $1 \mathrm{~L}$ of water. The detection was made at $253 \mathrm{~nm}$ for sorbic acid and chromatographic separation was carried out on Supelcosil LC-ABZ $250 \mathrm{~mm}$ x $4.6 \mathrm{~mm}, 5 \mathrm{~mm}$ (Supelco, Bellefonte, PA, USA) or equivalent column with $20 \mu \mathrm{l}$ injection.

The gradient elution details were as follows:

Table 2. Gradient Programme

\begin{tabular}{ccc}
\hline Time (min) & Acetonitrile (A\%) & Buffer (B\%) \\
\hline 0 & 25 & 75 \\
10 & 25 & 75 \\
22 & 75 & 25 \\
25 & 25 & 75 \\
\hline
\end{tabular}




\subsection{Preparation of standard solutions}

Appropriate amount of standard benzyl alcohol was weighed into a volumetric flask and maked up with methanol. Stock standard solution was diluted by methanol in order to make final concentrations between $1.0-5.0 \mathrm{mg} / 100 \mathrm{ml}$ and prepare a calibration curve.

$20 \mathrm{mg}$ sodium benzoate working standard was weighed and transferred into a $200 \mathrm{ml}$ volumetric flask. $150 \mathrm{ml}$ of mobile phase added. Sonicated and maked up the volume with mobile phase. $25 \mathrm{ml}$ of this solution diluted to $100 \mathrm{ml}$ with mobile phase.

Essential quantity of standard sorbic acid was weighed and series of dilutions were prepared in the concentration range from 1.0 to $5.0 \mathrm{mg} / 100 \mathrm{ml}$ diluting by methanol.

The calibration graphs were constructed from five consecutive injections over the covered ranges of concentrations.

\subsection{Sample Preparation}

Samples of various cosmetic matrices were prepared from four different pharmaceutical forms of cosmetics. These are solution, gel, emulsion and cream forms.

\section{Sample preparation for benzyl alcohol}

Approximately $1 \mathrm{~g}$ of the sample was weighed and added $6 \mathrm{~mL}$ of methanol, then the samples were sonicated in an ultrasonic bath for 15 minutes. Later transferred quantitatively into a $10.0 \mathrm{~mL}$ volumetric flask, filled to the mark with methanol and mixed. Then the solutions filtered through a nylon filter with a pore size of $0.20 \mu \mathrm{m}$ and the obtained filtrates analysed by the HPLC method (where necessary, dilute samples with methanol or water). All sample injections conducted triplicate.

\section{Sample preparation for sodium benzoate}

$1 \mathrm{~g}$ sample was transfered into a $200 \mathrm{ml}$ volumetric flask, added $150 \mathrm{ml}$ mobile phase. Sonicated and maked up the volume with mobile phase. $25 \mathrm{ml}$ of this solution diluted to $100 \mathrm{ml}$ with mobile phase. All sample injections conducted triplicate.

\section{Sample preparation for sorbic acid}

$1 \mathrm{~g}$ sample was weighed into a $100 \mathrm{ml}$ flask with an emery stopper. $40 \mathrm{ml}$ of methanol, $0.5 \mathrm{ml} 2 \mathrm{M}$ sulphuric acid and anti-boiling granules were added. The cap was screwed and shaked at least 1 minute until a homogeneous suspension was obtained. The flask was placed into an ultrasonic bath termostated at $60^{\circ} \mathrm{C}$, immediately cooled and transfered into a $50 \mathrm{ml}$ volumetric flask. The solution was filled up to volume with mixture of eluent A / eluent B (1:3). The exract was placed at $5^{\circ} \mathrm{C}$ for 1 hour, and passed through $0.45 \mathrm{~mm}$ membrane filter. The analysis was performed within 24 hours. Sample solution was diluted with the eluent mixture in order to fall within calibration range. All sample injections conducted triplicate.

\section{Results and Discussion}

Obtained results from solution, emulsion, gel and cream forms of cosmetic matrices showed that the analyses methods applied for qualitative and quantitative determination of benzyl alcohol, benzoic acid and sorbic acid were found as applicable 
for four different pharmaceutical forms (liquid, gel, emulsion and cream) used in cosmetic products. All the results were in the limits of cosmetic legislation for all types of matrices. The aim of this study was practicing and adapting the indicated methods for detection and quantification of preservatives in different references for different pharmaceutical forms to reach the easy applicable, repeatable and valide methods. In this context, replicate analysis were carried out on different types of cosmetic matrices, it was found that the results were repeatable, statistically significant and acceptable for quality control test procedure. Overall runtimes are shorter, thus reduce analysis time. Thus the proposed HPLC-UV methods in this study can be used as practical and acceptable methods to assess the preservative use for various cosmetic products having different forms and matrices. Also the methods can be adapted to similar chemical structure preservatives.

\section{Conclusion}

In conclusion, the applied HPLC-UV methods in this study can be used for the determination of benzyl alcohol, benzoic acid and sorbic acid in various cosmetic products. The methods provide a rapid, accurate, sensitive and reproducible means of determining target elements with simple sample preparations. Then the analytical procedures proposed in this study can be used effectively for the quality control analysis of cosmetic samples and quasi drugs accepted as cosmetics that are commercially available on the market. 19

\section{References}

Nair B., Final Report On The Safety Assessment of Benzyl Alcohol, Benzoic Acid, and Sodium Benzoate, Int J Toxicol., 2001, 20 (3):23-50.

http://www.titck.gov.tr/Mevzuat

http://ec.europa.eu/health/scientific_committees/consumer_safety/docs/sccs_o_073.pdf

https://ec.europa.eu/health/sites/health/files/endocrine_disruptors/docs/cosmetic_1223_2009_regulati on_en.pdf

Nogal Sánchez M., Pérez-Pavón J.L., Moreno Cordero B. Determination of Suspected Allergens in Cosmetic Products by Head Space-Programmed Temperatur Evaporization-Fast Gas ChromatographyQuadrupole Mass Spectrometry, Anal Bioanal Chem., 2010, 397(6), 2579-91.

Baranowska I., Wojciechowska I. The Determination of Preservatives in Cosmetics and Environmental Waters by HPLC, Pol. J. Environ. Stud., 2013, 22(6),1609-25.

Baranowska I., Wojciechowska I. Determination of Preservatives in Cosmetics, Cleaning Agents and Pharmaceuticals Using Fast Liquid Chromatography Journal of Chromatographic Science, 2014, $52(1,1), 88-94$.

Concise International Chemical Assessment Document 26 Benzoic Acid and Sodium Benzoate, World Health Organization, 2000, http://www.who.int/ipcs/publications/cicad/cicad26_rev_1.pdf

Türkiye İlaç ve Tıbbi Cihaz Kurumu, Organik ve Doğal Kozmetik Ürün İddialarına İlişkin Kılavuz, 2015.

T.C. Sağlık Bakanlığı Kozmetik Yönetmeliği, Resmi Gazete, 2005, Sayı 25823.

EC 1223/2009 - European Commission.

Mikami E., Goto T., Ohno T., Matsumoto H., Nishida M. Simultaneous Analysis of Dehydroacetic Acid, Benzoic Acid, Sorbic Acid and Salicylic Acid in Cosmetic Products by Solid-Phase Extraction And High-Performance Liquid Chromatography, Journal of Pharmaceutical and Biomedical Analysis, 2002, 28 (2), 261-7.

Gao W., Quigley C.L. Fast and Sensitive High Performance Liquid Chromatography Analysis of Cosmetic Creams for Hydroquinone, Phenol and Six Preservatives, Journal of Chromatography A, 2011, 1218 (28), 4307-11. 
Bousquet E., Spadaro A., Santagati N.A., Scalia S., Ronsisvalle G. Determination of Undecylenic and Sorbic Acids in Cosmetic Preparations by High Performance Liquid Chromatography with Electrochemical Detection, J.Pharm.Biomed Anal., 2002, 7;30(4), 947-954.

Saad B., Bari Md.F., Saleh M.I., Ahmad K., Mohd.Talib M.K. Simultaneous Determination of Preservatives (Benzoic Acid, Sorbic Acid, Methylparaben And Propylparaben) in Food Stuffs Using HighPerformance Liquid Chromatography, Journal of Chromatography A, 2005, 1073 (1-2), 393-397.

Fung Y.S., Luk S.F. Polarographic Determination of Sorbic Acid in Fruit Juices and Soft Drinks Analyst, 1990, 115, 1219-1221.

Alğın Yapar E., Haspolat F.E. Farmakope Metotlarında Kromatografik Test Parametrelerinin Ayarlanabilirliği, Türk Farmakope Dergisi, 2018, 3(1):25-37. 1.

Determination of Some Preservatives by HPLC, Analytical Methods for Cosmetics, 2004, 300-303.

The Pharmaceutical Affairs Act of Japan, https://www.mhlw.go.jp/english/. 